\title{
Potential Impact of Wash Bay Effluent on the Water Quality of a Subtropical River
}

\author{
Concilia Danha1, Beaven Utete ${ }^{2 *}$, Gabriel Soropa ${ }^{3}$, Simbarashe B. Rufasha1 \\ ${ }^{1}$ Department of Environmental Science and Technology, Chinhoyi University of Technology, \\ Chinhoyi, Zimbabwe \\ ${ }^{2}$ Department of Wildlife Ecology and Conservation, Chinhoyi University of Technology, \\ Chinhoyi, Zimbabwe \\ ${ }^{3}$ Department of Irrigation and Water Engineering, Chinhoyi University of Technology, \\ Chinhoyi, Zimbabwe

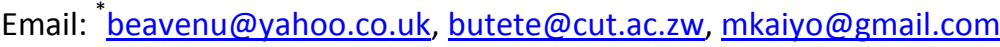

Received 5 May 2014; revised 2 June 2014; accepted 25 June 2014

Copyright (C) 2014 by authors and Scientific Research Publishing Inc.

This work is licensed under the Creative Commons Attribution International License (CC BY). http://creativecommons.org/licenses/by/4.0/

c) (i) Open Access

\begin{abstract}
Washbay effluents have received scant attention as a potential source of water pollution globally. This study is the first to investigate the potential impact of the total wash bay effluent content released into river water in Africa. We investigated the potential ramifications of wash bay effluxent released off Charter Estates, Chimanimani in the Eastern Highlands of Zimbabwe on the water quality of the receiving subtropical Nyahode River by measuring selected water limnochemical aspects which included biological oxygen demand (BOD), chemical oxygen demand (COD), oil and grease, $\mathrm{pH}$, sulphates, phosphates, iron, total suspended solids (TSS), dissolved oxygen (DO) and electrical conductivity (EC) once every 3 months from October 2011 to July 2012. The obtained mean levels of the limnochemical parameters from the Nyahode River were compared to the local Environmental Management Agency (EMA) and international World Health Organisation (WHO) effluent standards. Our results show that the control point and the off effluent discharge source downstream points in the Nyahode River had water quality parameters that were below the local EMA and WHO water quality threshold values. Cluster analysis showed a strong linkage in the values of water quality parameters measured at sampling sites 3 and 4 which were below the discharge point. Wash bay effluent released from the Charter Estate has an impact on some aspects of the water in the Nyahode River but the river has a functional self-purification capacity. Onsite industrial purification of wash bay effluent before discharge reduces its potential deleterious impact on water quality, river habitat integrity and aquatic biodiversity.
\end{abstract}

\section{Keywords}

Hydrocarbon, Impact, Pollution, River Integrity, Self-Purification

\footnotetext{
${ }^{*}$ Corresponding author.
}

How to cite this paper: Danha, C., Utete, B., Soropa, G. and Rufasha, S.B. (2014) Potential Impact of Wash Bay Effluent on the Water Quality of a Subtropical River. Journal of Water Resource and Protection, 6, 1045-1050. 


\section{Introduction}

Lotic systems provide vital ecosystem services that warrant their protection and conservation [1] but they face a plethora of challenges mainly as a consequence of anthropogenic activities [1] [2]. A car wash bay is an area or structure equipped with facilities for washing automobiles [3]. In industrial sectors car wash bays are used to wash small to heavy machinery. However, the effluent generated from car wash bay systems will find its way into the environment thereby posing threat to our environment [4]-[8] as it has the potential to either contaminate or pollute. Studies elsewhere have shown that effluent and run-off from vehicle washing and cleaning activities can damage the environment and pollute rivers, streams, burns and groundwater [9]. Dirt, brake dust, traffic film residue and oil that are washed off are all pollutants. Cleaning agents used including those labelled biodegradable or traffic film removers are very poisonous to river life [2].

Since 2009, the effluent released into Nyahode River from the car wash bay at Charter Estate in Chimanimani, Zimbabwe has been mostly licenced in red or yellow class according to the Environmental Management Agency (EMA) standards [6]. Resultantly, the residents of the Charter Estate area have noted a great deterioration in fish fauna diversity along the Nyahode River. This could be so as car wash bay effluent is known to contain traces of oils, greases, detergents and heavy metals pollutants some of which are classified as hazardous [10] [11]. Wastewater from the wash bay system at Charter Estate is being discharged into Nyahode River but there have been limited scientific studies to investigate its potential impact on water quality and consequently the resident aquatic flora and fauna. This study aims to assess the impact of wash bay effluent on Nyahode River water quality.

\section{Materials and Methods}

\subsection{Study Area and Study Design}

The study was conducted at Nyahode River, Chimanimani which is located in Manicaland Province in the Eastern Highlands of Zimbabwe between latitudes $19^{\circ} 45^{\prime}-20^{\circ} 03^{\prime} \mathrm{S}$ and longitudes $32^{\circ} 45^{\prime}-33^{\circ} 02^{\prime} \mathrm{E}$ with an elevation of $486 \mathrm{~m}$ above sea level. It is a tributary of the Rusitu River. The stream exhibit high streambed roughness with the predominant substratum being a mixture of cobble, pebble and boulders. Along its length the river is bordered by timber estates consisting of mainly pine trees (Pinus patuda, P. taeda and P. elliottii) and gum trees (Eucalyptus grandis, E. saligna and E. cloeziana). Among these estates is Charter Estate where washbay effluent is being discharged directly into the river. Four sites for the assessment of various water quality aspects were chosen on the study site. Site $1\left(19^{\circ} 45^{\prime}-20^{\circ} 03^{\prime} \mathrm{S} ; 32^{\circ} 45^{\prime}-31^{\circ} 02^{\prime} \mathrm{E}\right)$ which was the control point and is located upstream of the wash bay effluent discharge drains. Site $2\left(19^{\circ} 45^{\prime}-20^{\circ} 03^{\prime} \mathrm{S} ; 32^{\circ} 45^{\prime}-28^{\circ} 02^{\prime} \mathrm{E}\right)$ was located at the wash bay effluent discharge point and was designated as sampling point 1 . This site is characterised by boulders in river channel. Site $3\left(19^{\circ} 45^{\prime}-20^{\circ} 03^{\prime} \mathrm{S} ; 32^{\circ} 45^{\prime}-27^{\circ} 02^{\prime} \mathrm{E}\right)$ was located downstream of the Nyahode River and is designated as sampling point 2 and is characterised by dense riparian vegetation, and emergent rocks in channel. Site $4\left(19^{\circ} 45^{\prime}-20^{\circ} 03^{\prime} \mathrm{S} ; 32^{\circ} 45^{\prime}-26^{\circ} 02^{\prime} \mathrm{E}\right)$ designated as sampling point 3 was the furthermost site consisting of emergent aquatic macrophytes dominated by exotic weeds and trees particularly the Psidium guajava.

\subsection{Water Quality Sampling and Analysis}

Water samples were collected four times at each site, once every 3 months from October 2011 to July 2012using the grab sampling method. The samples were collected using two litre-polythene bottles after being rinsed with the sample water at the sampling sites. All the samples were tightly closed, labelled and taken to the laboratory for analysis. The samples were analyzed for BOD, COD, Oil and grease, $\mathrm{pH}$, Sulphates, Phosphates, Iron, and TSS. At each site DO, EC and pH was measured using electronic meters. Total Suspended Solids were measured by the Gravimetric Method. Total phosphates were determined by the (UV - VIS Spectrophotometer). Iron in water was determined by the acidification process and quantified by the Flame Atomic Absorption Spectrophotometry (FAAS).

Chemical Oxygen Demand was determined by the Open reflux [12]. Biochemical Oxygen Demand was determined using the $B O D_{5}$ (5 day BOD method) [13].

$$
B O D_{5}(\mathrm{mg} / \mathrm{L})=\frac{D 1-D 2}{P}
$$

where: $D 1=$ initial sample dissolved-oxygen (DO) concentration (in $\mathrm{mg} / \mathrm{L}$ ) $D 2=$ sample $\mathrm{DO}$ (in $\mathrm{mg} / \mathrm{L}$ ) after 5 
days $P$ = decimal volumetric fraction of sample used.

\subsection{Data Analysis}

One way Analysis of variance (ANOVA) was used to compare means of physicochemical variables and their temporal variation among sampling sites after testing for normality (Shapiro-Wilk test)and homogeneity of variance (Levene's test). Pair wise comparison of the limnochemical parameters was done using the Tukey's test at 5\% level. Cluster analysis was performed using the Morisita Similarity Index. ANOVA was performed using (Systat 12 for Windows version 12.02 .00 [14]. The means of the physicochemical parameters were compared to the local environmental authority (EMA) and the International (WHO guideline values) values.

\section{Results}

\section{Limnochemistry of Water}

Results obtained from the study showed that there was a significant difference in BOD levels among the sampled sites (ANOVA, $\mathrm{p}<0.05$ ). Pair wise comparison of the BOD values showed that site 4 differed significantly with the sites 3 and 2 (Tukey's test, $\mathrm{p}<0.05$ ). There was significant temporal/monthly variation (ANOVA, $\mathrm{p}<$ $0.05)$ in the BOD levels across sampled sites. Mean BOD values at the discharge site $(42.1 \pm 1.56 \mathrm{mg} / \mathrm{L})$ and site 3/sampling point $2(38.9 \pm 3.09 \mathrm{mg} / \mathrm{L})$ were significantly above the local EMA and WHO threshold values of $30 \mathrm{mg} / \mathrm{L}$ (Table 1). Our results showed a significant difference (ANOVA, p < 0.05) in COD levels among the sampled sites. Pair wise comparison of the COD values showed that there was a significant difference (Tukey's test, $\mathrm{p}<0.05$ ) between (discharge point vs. control site: control site vs. sampling point 2/site 3: discharge vs. sampling point 2: discharge point vs. sampling point 3/site 4). There was significant temporal variation (ANOVA, $\mathrm{p}<0.05$ ) in COD values in each of the sites sampled in this study. Mean COD values at the discharge site $(310.8 \pm 16.65 \mathrm{mg} / \mathrm{L})$, sampling point $2(167.8 \pm 36.68 \mathrm{mg} / \mathrm{L})$ and sampling point 3/site $4(96.3 \pm 7.69 \mathrm{mg} / \mathrm{L})$ were significantly above the local EMA and WHO guideline values of $60 \mathrm{mg} / \mathrm{L}$.

Significant differences (ANOVA, $\mathrm{p}<0.05$ ) were observed in oil and grease values among the sites sampled in this study. Pair wise comparison of the oil and grease levels revealed a significant difference (Tukey's test, $\mathrm{p}<$ 0.05 ) between (control point and all sites sampled; discharge point vs. sampling points 2 and 3, sampling point 2 vs. sampling point 3). There was no significant temporal/monthly variation (ANOVA, p > 0.05) in the oil and grease levels across sampled sites. Mean oil and grease values at the discharge point $(6.5 \pm 0.24 \mathrm{mg} / \mathrm{L})$ and sampling point 2/site $3(4.1 \pm 0.31 \mathrm{mg} / \mathrm{L})$ were above the local EMA and WHO threshold values of $2.5 \mathrm{mg} / \mathrm{L}$. The results of the study showed that $\mathrm{pH}$ values did not differ significantly (ANOVA, $\mathrm{p}>0.05$ ) among sampled sites and as well there was no significant temporal variation (ANOVA, $\mathrm{p}>0.05$ ) across sites. Pair wise comparison also revealed no significant differences (Tukey's test, $\mathrm{p}>0.05$ ) in $\mathrm{pH}$ values in all the sites sampled. Mean $\mathrm{pH}$ values at all sites were within the 6.5 - 9 local EMA and WHO threshold values. Mean TDS values differed significantly (ANOVA, p < 0.05) among sampled sites. However, there was significant temporal variation (ANOVA, $\mathrm{p}<0.05$ ) in total suspended solids in all the sampled sites. Pairwise comparison reveals significant differences (Tukey's test, $\mathrm{p}<0.05$ ) in TSS values between (discharge vs. control: discharge vs. sampling sites 2 and 3). Mean TSS values in discharge point $(171.3 \pm 39.66 \mathrm{mg} / \mathrm{L})$, sampling point $2(74.8 \pm 9.04 \mathrm{mg} / \mathrm{L})$ and sampling point $3(36.0 \pm 8.85 \mathrm{mg} / \mathrm{L})$ were significantly above the local EMA threshold values of $25 \mathrm{mg} / \mathrm{L}$.

Iron concentrations differed significantly (ANOVA, p < 0.05) among sampled sites. Pairwise comparison show that significant differences (Tukey's test, $\mathrm{p}<0.05$ ) in iron concentrations in the Nyahode River were observed between (discharge site vs. control site: discharge site vs. sampling point 3/site 4). Mean iron levels at the discharge point $(3.3 \pm 1.06 \mathrm{mg} / \mathrm{L})$ and sampling site $2(1.5 \pm 0.57 \mathrm{mg} / \mathrm{L})$ were above the local EMA and WHO threshold levels of $1 \mathrm{mg} / \mathrm{L}$ (Table 1). The concentrations of phosphates differed significantly (ANOVA, $\mathrm{p}<$ 0.05) among the sampled sites in the Nyahode River. Pair wise comparison of phosphate concentrations show a significant difference (Tukey's test, $\mathrm{p}<0.05$ ) between (control vs. discharge: discharge site vs. sampling point $3)$. Mean phosphate levels at the discharge site $(0.8 \pm 0.13 \mathrm{mg} / \mathrm{L})$ were above the local EMA and WHO threshold levels of $0.5 \mathrm{mg} / \mathrm{L}$. Concentrations of dissolved oxygen did not differ significantly among the sites sampled (ANOVA, $p>0.05$ ). Pair wise comparison also revealed no significant differences in DO concentrations in sites sampled (Tukey's test, $\mathrm{p}>0.05$ ). There was no temporal variation in the dissolved oxygen concentration in the sites sampled (ANOVA, $\mathrm{p}>0.05$ ). The DO values in all the samples sites were above the local EMA and 
Table 1. Mean \pm SD of the environmental variables of four sampling sites in Nyahode River from October 2011 to July 2012.

\begin{tabular}{ccccccc}
\hline Parameter/Site & Control & Discharge point & S.P 2 & S.P 3 & EMA $^{*}$ & WHO $^{*}$ \\
\hline BOD $(\mathrm{mg} / \mathrm{L})$ & $32.4 \pm 6.67$ & $42.1 \pm 3.12$ & $38.9 \pm 6.19$ & $22.3 \pm 5.56$ & 30 & 30 \\
COD $(\mathrm{mg} / \mathrm{L})$ & $50.1 \pm 10.37$ & $310.8 \pm 33.29$ & $167.8 \pm 73.13$ & $96.3 \pm 15.37$ & 60 & 60 \\
Oil \&grease $(\mathrm{mg} / \mathrm{L})$ & $0.9 \pm 0.13$ & $6.5 \pm 0.48$ & $4.1 \pm 0.62$ & $2.5 \pm 0.97$ & 2.5 & 2.5 \\
pH & $6.8 \pm 0.58$ & $7.0 \pm 0.23$ & $6.9 \pm 0.07$ & $6.9 \pm 0.13$ & $6-9$ & $6.5-9$ \\
TSS mg/L & $22.8 \pm 10.90$ & $171.3 \pm 79.32$ & $74.8 \pm 18.08$ & $36.0 \pm 17.70$ & 25 & 25 \\
Iron mg/L & $0.4 \pm 0.22$ & $3.3 \pm 2.12$ & $1.5 \pm 1.14$ & $0.6 \pm 0.25$ & 1 & 1 \\
Phosphates $(\mathrm{mg} / \mathrm{L})$ & $0.2 \pm 0.04$ & $0.8 \pm 0.27$ & $0.5 \pm 0.16$ & $0.3 \pm 0.10$ & 0.5 & 0.5 \\
DO mg/L & $8.9 \pm 1.42$ & $9.6 \pm 4.69$ & $9.5 \pm 1.58$ & $8.55 \pm 1.4$ & 5.0 & 5.0 \\
Conductivity $(\mu \mathrm{S} / \mathrm{cm})$ & $124.8 \pm 62.66$ & $231.5 \pm 89.27$ & $179.5 \pm 81.52$ & $134.3 \pm 69.03$ & 1000 & 1000 \\
\hline
\end{tabular}

Note: SP 2 = Sampling point 2/site 3; SP 3 = Sampling point 3/site 4. Local (EMA) and international (W.H.O) effluent standards are highlighted by an asterik.

international WHO threshold values. There was no significant difference in the conductivity among sampled sites (ANOVA, p > 0.05). However, there was a significant temporal difference (ANOVA, $p<0.05$ ) in electrical conductivity with significantly high values recorded in the month of July in all sites sampled in this study. The mean conductivity values were below the local EMA and WHO threshold values of $1000 \mathrm{u} \mathrm{S} / \mathrm{cm}$ (Table 1).

Cluster analysis showed a similarity between sampling points $2 \& 3$ (sites $3 \& 4$ ) which were located immediately below the discharge point. The discharge point shows a clear aberration from all the sites sampled in all aspects of water quality and linkage distance was longest between the discharge point and the control point (Figure 1).

\section{Discussion}

Wash bay effluent comprises mainly of oil and grease which have potential impact on the water quality of the effluent receiving waters. The results obtained from the study showed that wash bay effluent from the Charter Estates is impacting on the water quality of the Nyahode River. An assessment conducted on the water quality showed that the discharge point had some parameters that were above the local Environmental Management Agency and World Health Organisation aquatic effluent threshold values. These aspects include BOD, COD, oil and grease, total suspended solids, iron and phosphate concentrations. The control point, and the downstream points that we sampled had water quality aspects that were below or satisfied the local EMA and W.H.O. threshold values. This study therefore revealed that the wash bay effluent released from the Charter Estate has an impact on some aspects of the water quality in the Nyahode River; and they in turn show that the Nyahode River has a functional self-purification capacity as the water quality sampled after the discharge point at sampling points 2 and 3 was better in all aspects. This is in agreement with research studies done in Mukuvisi River which support the notion that rivers have a self-purification capacity that helps in maintaining their biophysical integrity [10] [11] [15].

From the few isolated impact assessment studies done elsewhere it has been shown that hydrocarbon laden wash bay discharge/effluent impacts negatively on aquatic ecosystems [16]. Some of the impacts include cutting off oxygen and carbon dioxide diffusion into lotic systems thereby inducing hypoxia in some aquatic organisms [17] [18]. However, despite the blockage effect by oil and grease the dissolved oxygen concentrations we recorded in the Nyahode River were within the acceptable local and international threshold limits. This may be explained by the fact that the river is fast flowing with intermittent rapids along its course which improve oxygenation of the water and the fact that it drains undisturbed deciduous forest catchments [4]. Oil and grease also affect decomposers such as shredders, floating and visual feeding aquatic organisms by reducing visibility and attenuate light thereby limiting photosynthesis [5]. The oil and grease attach to leaves and sediments reducing gaseous diffusion into plants [7]. Nutrients released from wash bay effluents like the phosphates that were in high concentrations at Charter Estates discharge point promote rampant algal growth and promote weed growth. At the discharge point there was rampant algal growth with a slimy appearance. Wash bay effluent contains metals and in our study we found high concentrations of iron at the discharge point. This metal has toxic effects on aquatic organism especially macro invertebrates and fish [12]. 


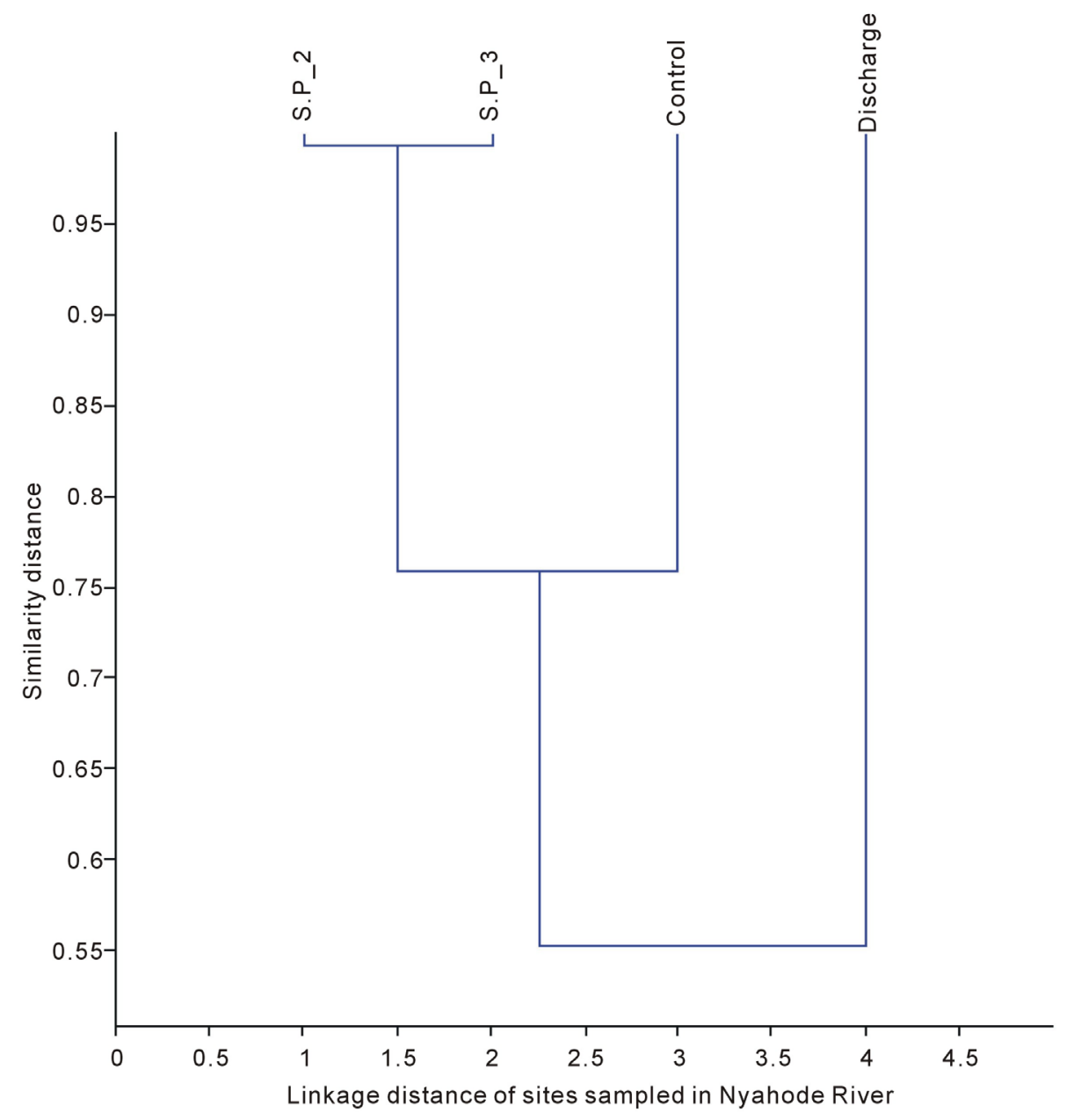

Figure 1. Cluster analysis of sites sampled in the Nyahode River. Note: SP2 = Sampling point 2 and SP3 = Sampling point 3.

Cluster analysis shows a close similarity in most aspects of water quality at sampling sites $2 \& 3$ which are located directly below the discharge point. However, there is a clear deviation in water quality at the control point relative to the discharge point. This means that the Charter Estate wash bay effluent discharge point has an impact on some aspects of the water quality in the Nyahode River. This investigation was a preliminary assessment of impact of the total wash bay effluent content on some aspects of water quality in a lotic system. The highlights were the variance of some aspects of the Nyahode River water quality from the local and international effluent standards which point to potential deleterious impact of wash bay effluent on river habitats. However, it can be conceded that in addition to the episodic water monitoring a strengthening component like biomonitoring of the river using a raft/spectrum of aquatic organisms like macro invertebrates [4], fish fauna, aquatic macrophytes, rotifers and diatoms [1] could be implemented before a conclusive picture can be painted.

This study shows that the wash bay effluent has an impact on some aspects of water quality in a river. Although we concede that the sampling efforts could have been increased to improve the quality of the results our hope is that we have kick-started the analysis and monitoring of wash bay effluents that has a dearth and scarcity of literature especially in Africa. In as much as it is prudent to analyse the fractions constituting the whole wash bay effluent component as they are more specific pointers to the toxicity of a specific hydrocarbon, our aim was to investigate the potential impact of the total wash bay effluent content on receiving lotic waters. In future studies other ecohydrological factors can be considered like the sediment loading, the wash bay effluent discharge volume, river width channel, riparian vegetation composition as well as the aquatic fauna diversity in order to obtain an accurate assessment of the impact of wash bay effluent on lotic ecosystems. 


\section{Acknowledgements}

We thank the management of the Charter Estate who allowed us to sample the adjacent Nyahode River and analyse the samples in their premises.

\section{References}

[1] Bere, T., Phiri, C, Kadye, W. and Utete, B. (2013) Benthic Diatom Assemblages in Mountain Streams: Community Structure in Relation to Environmental Pressures. African Journal of Ecology, 51, 625-634. http://dx.doi.org/10.1111/aje.12078

[2] Brown, C. (2002) Water Use and Wastewater Discharge in Professional Car Washes. International Carwash Association Report, Chicago.

[3] Camp, D. and McKee, C.D.M. (1993) California Storm Water Industrial/Commercial Best Management Practice Handbook. Stormwater Quality Task Force, Sacramento, CA.

[4] Chakona, A. (2005) The Macroinvertebrate Communities of Two Upland Streams in Eastern Zimbabwe with Reference to the Impact of Forestry. Ms.C. Thesis, University of Zimbabwe, Harare, 12-24.

[5] Edema, N.E. and Etioyibo, E.L. (1999) The Effect of Amukpe Flowstation Crude Oil on Germination, Height, Fresh and Dry Weight of L. esculentum and A. esculentus. Transactions of the Nigeria Society for Biological Conservation, 6 , 4-12.

[6] EMA (2011) Effluent Standards for Streams. EMA Publications, Zimbabwe.

[7] EPA (2003) The Behaviour and Effects of Oil Spills in Aquatic Environments, Understanding Oil Spills and Oil Spill Response. EMA Publications, Zimbabwe

[8] Hammer, M.J.J. and Hammer Jr., M. (2001) Water and Wastewater Technology. 4th Edition, Prentice-Hall Inc Pvt Ltd., Upper Saddle River.

[9] International Car Wash Association (2008) ICA Study of Consumer Car Washing Attitudes and Habits.

[10] Machena, C. (1997) The Self-Purification Capacity of the Mukuvisi River. In: Moyo, N.A.G. (Eds.), Lake Chivero, a Polluted Lake, University of Zimbabwe Publications, Harare.

[11] Ndebele, R.M.(2012) Biological Monitoring and Pollution Assessment of the Mukuvisi River, Harare, Zimbabwe. Lake and Reservoirs: Research and Management, 17, 73-80.

[12] Nhiwatiwa, T., Barson, M., Harrison, A.P., Utete, B. and Cooper, R.G. (2011) Metal Concentrations Insharptooth Catfish (Clarias gariepinus, Burchell 1822), Sediments and Water in Peri-Urban Rivers in Zimbabwe. African Journal of Aquatic Sciences, 3, 243-252. http://dx.doi.org/10.2989/16085914.2011.636906

[13] Pit Well. STANDARD COD. (1983) Chemical Brittania, 19, 907.

[14] Systat (2007) Mystat: A Student Version of Systat 32 Bit UNICODE English, Version 12.02.00.

[15] Tendaupenyu, I.H. (2000) The Self-Purification Capacity of the Mukuvisi River. Bsc Thesis, University of Zimbabwe, Harare.

[16] Wake, A. (2005) The Effects of Oils and Oil Components on Algae: A Review. Bryological and Phycological Journal, 11, 115-142.

[17] Yoshida, I. and Yasui, T. (1992) Studies on the Self-Purification of Rivers. Bulletin of Faculty of Agriculture, Tottori University, 45, 33-38.

[18] Zambrano, J. and Carballeira, A. (1999) Effects of Hydrocarbons on the Physiology and Growth of. Ulva sp. (Chlorophyta). Boletin. Instituto. Espanol. De Oceanografia, 15, 373-381. 
Scientific Research Publishing (SCIRP) is one of the largest Open Access journal publishers. It is currently publishing more than 200 open access, online, peer-reviewed journals covering a wide range of academic disciplines. SCIRP serves the worldwide academic communities and contributes to the progress and application of science with its publication.

Other selected journals from SCIRP are listed as below. Submit your manuscript to us via either submit@scirp.org or Online Submission Portal.
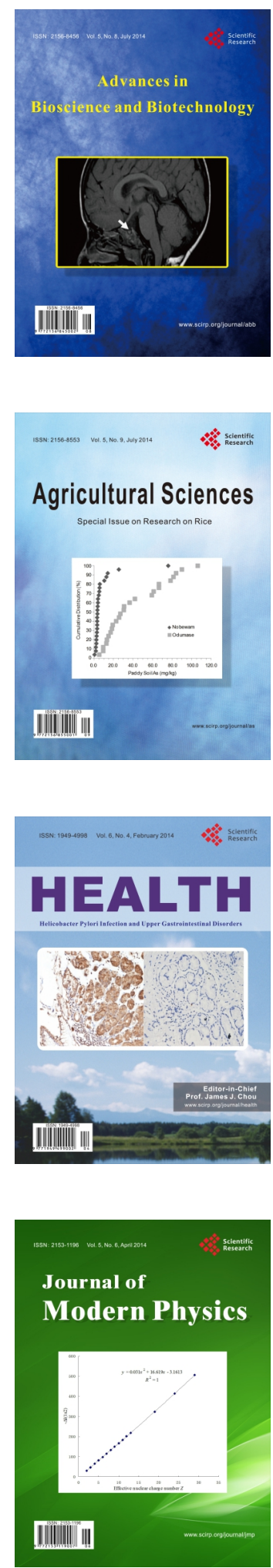
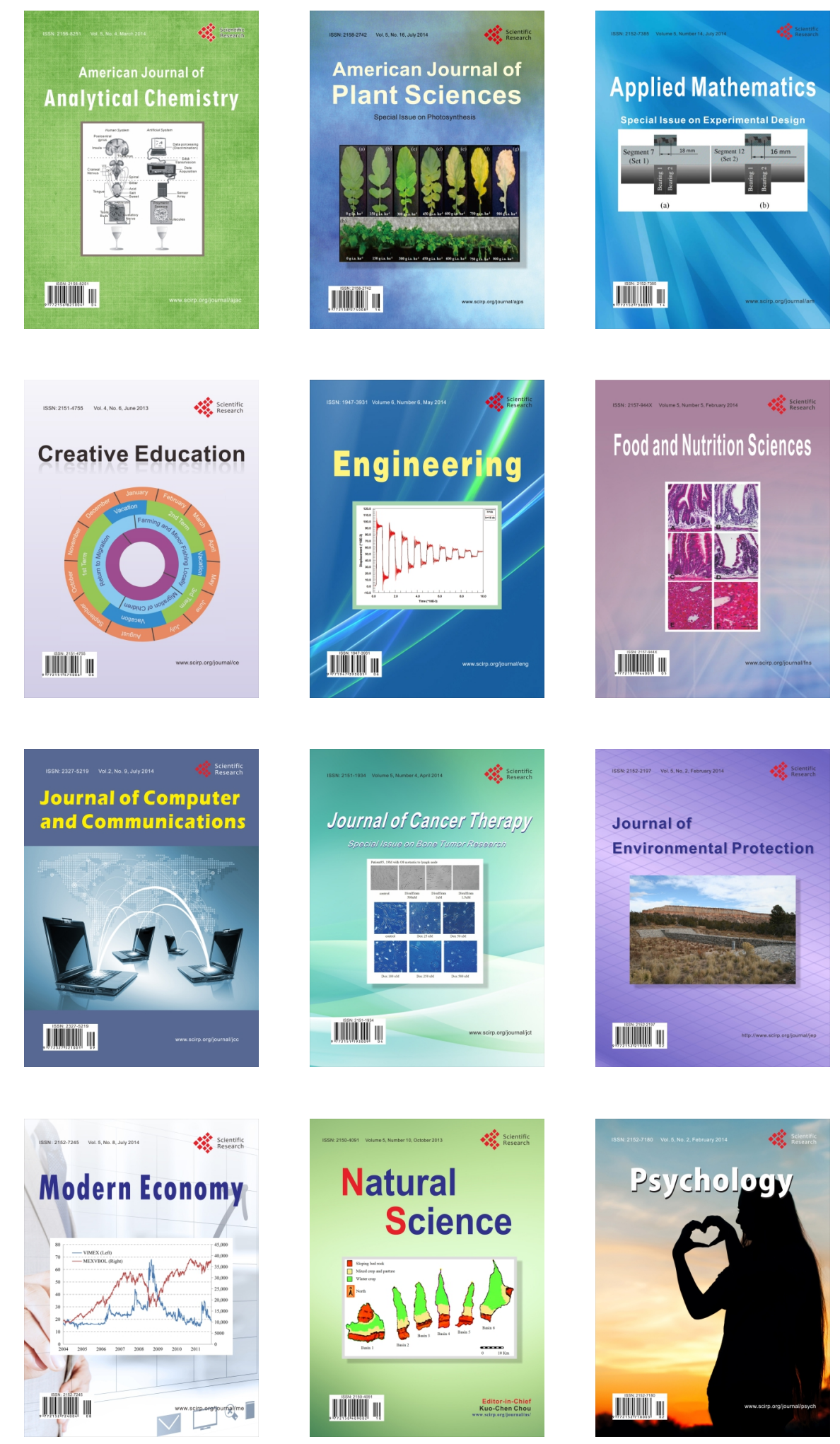